\title{
Comparative study of leaf morphology, phytochemical, mineral and proximate analysis of Codiaeum variegatum (L.) A. Juss. (Malpighiales: Euphorbiaceae) and its stable mutant
}

\section{Esan Edward Babatunde ${ }^{1}$, Adaramola Feyisara Banji ${ }^{1 *}$, Odutayo Foluke$^{1}$, Aina David Ayandiran² ${ }^{2}$ and Kotun Fatima ${ }^{1}$}

${ }^{1}$ Department of Basic Sciences, Babcock University, Ilishan- Remo Ogun State, Nigeria. Email:*Email: feyimicheal37@gmail.com.

2Department of Microbiology, Babcock University, Ilishan-Remo Ogun State, Nigeria.

\begin{abstract}
Differences in terms of morphology, phytochemical, mineral and proximate compositions created as a result of a natural spontaneous mutation that produced a stable bud-sport on the vegetative parent body of a member of the Euphorbiacea Family Codiaeum variegatum cv. ovalifolium was compared. Morphological characterization of the leaves was done by leaf skeletonization, proximate and mineral analyzes were carried out by method of Association of Official Analytical Chemists while the phytochemical screening was carried out on $80 \%$ methanol extracts of the leaves using standard methods. From the results of the morphological characteristics, the mutant showed more vegetative vigor than the parent plant. Results of phytochemical screening showed that; while flavonoid was absent in both, cardiac glycosides and tannins were highly present in the parent but slightly present in the mutant. For both mutant and the parent, calcium had the highest concentration. Copper was absent in the parent while it occurred at the lowest concentration in the mutant. Also, the concentrations of magnesium, potassium, phosphorus, iron and zinc were higher in the parent plant. Results of proximate composition of the plants showed that both mutant and the parent plant have high nutritive values. Conclusively, the morphological characters of the mutant were shown to distinctly differ from those of the parent plant. Also, both the mutant and its parent plant showed considerably good amount of important phytochemicals, minerals and proximate compositions, making them good prospects for food and medicine.
\end{abstract}

Keywords: Garden croton; Mineral; Morphology; Mutant; Phytochemical; Proximate.

\section{Introduction}

The story of plant evolution is mainly of gradually improving adaptation to life on land (Taylor et al., 2002). A plant begins its life cycle as a one-celled zygote,
Received January 25, 2017

Accepted

June 10, 2017

Released

June 30, 2017

Open Acess

Full Text Article

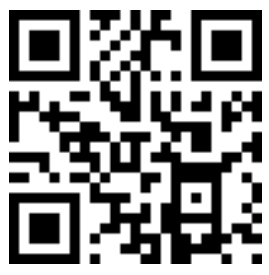

ORCID

(1) 0000-0003-1713-3670

Esan Edward Babatunde

(D) 0000-0001-5581-8377

Adaramola Feyisara Banji

(D) 0000-0001-5367-3469

Odutayo Foluke

D 0000-0002-4373-2530

Aina David Ayandiran

(D) $0000-0002-4325-8170$

Kotun Fatima a cell produced by the union of an egg cell with a sperm cell (fertilization). The zygote grows and develops into the embryo and finally into a fully mature plant. In the very young embryo, there is already a polarized differentiation into an axis composed of a 
root and a shoot with leaves attached to a stem. A typical leaf consists of at least nine parts (Dutta, 2004). The parts of a leaf include: the leaf-base, which is the attachment to the stem, the petiole, which is the leaf stalk and which may have swollen top and or bottom, known as the pulvinus. A mutation is usually defined as a permanent genetic change involving some part of the DNA molecule; thus producing a mutant of the parent plant. Mutations are spontaneous natural occurrences of changes as an integral process of evolution (Konokpa and Benzer, 1971). Horticulturists commonly refer to this as a “bud-sport” or "bud-mutation'. Mutation occurs spontaneously in various ways namely; chance rearrangement of the four bases in the DNA structure (point mutation); rearrangement of different parts of the chromosome (deletions, duplication, translocation and inversions); addition or subtraction of individual chromosomes (aneuploidy) or the multiplication of entire sets of chromosomes (polyploidy). Most mutations are deleterious, but occasionally a bud-sport may possess some horticultural merits inherent or latent in them (Campbell et al., 2008). When some mutants are cut off from the parent plant, propagated and cultivated, they may die or survive and become an independent plant cultivar. Similarly, the leaf mutation or mutants are equally more prominent, are readily visible and do occur in any part of any organism. Reports exist for leaf mutants on rice (Oryza sativa) Arabidopsis thaliana, tomato Lycopersicum esculemtum, and zombi weed leaves (Mwine and Damme, 2011; Xu et al., 2014).

Phytochemicals are bioactive compounds which are very vital in the knowledge of the therapeutic properties of plants. Some of such bioactive compounds, usually analyzed for, include alkaloids, tannins, anthraquinones, cardiac glycosides, flavonoids, saponins, phenols and phenolic compounds, phlobatanninis, terpenes, and essential oils (Campbell et al., 2008). Phytochemicals are the biologically active substances in plants that are responsible for giving them color, flavor and natural disease resistance. They appear to be powerful ammunition in the fight against many health disorders and especially cancer. To understand how phytochemicals protect the body from cancer, it is necessary to understand that cancer formation is a multistep process. Phyto-compounds seemingly combact cancer by interfering with one or more of the steps that lead to cancer (Balch and Balch, 2000).

Proximate analysis is to determine the total estimation of moisture, lipids (fats), ash (mineral), protein, carbohydrate and fiber that is present in a food. Some detailed information has been provided on Codieaeum variegatum (L.) A. Juss. (Malpighiales: Euphorbiaceae), more popularly known as the garden croton, and the enormity of leaf diversity with respect to leaf shape, size, color(s) and color combinations and especially frequent occurrence of mutants (bud-sport, sports or bud mutant) (Esan et al., 2005). However, Taylor (1938) had earlier stated that there were probably only six known basic species of Codieaum sp. from which all other cultivars known today have arisen mainly as mutants and rarely as hybrids and that the non-variegated cultivars (green leafed species) were probably the more primitive relative to the variegated cultivars (Fapohunda et al., 2005).

The intent of this research therefore was to determine the differences in the leaves of the mutant compared to the parent plant in terms of morphology, phytochemical, mineral and proximate composition and to explore the usefulness of the mutant plant for human benefits.

\section{Methodology}

\section{Sample collection}

Fresh samples of the cultivar of Codiaeum variegatum leaves (with identification number; BU SAT 1) were collected from the Babcock University Germplasm Repository (BUGR). Identification was carried out from the compiled checklist maintained on the stocks and verified by Systematists in the Department of Basic and Applied Sciences, Faulty of Science and Technology, Babcock University, Nigeria. The leaves 
were washed and air- dried for 3 weeks in the laboratory and oven dried at $40-45^{\circ} \mathrm{C}$ for $48 \mathrm{~h}$. The leaves were then pulverized with a mixer grinder (LEXUS MG-2053 OPTIMA) and subjected to phytochemical, proximate and mineral analysis. Every analysis was carried out in triplicates.

\section{procedures}

\section{Morphological characteristic}

The following steps were carried out:

- Ten samples of matured leaves (having green, yellow and maroon (purple) coloration at the back/ adaxial) of each cultivar (mutant and plant) were collected;

- Photocopies of all samples collected were made to produce leaf prints of each leaf and measurement of the desired characters were done accordingly;

- Another leaf skeletonization, also known as leaf print or printing , clearing or discolorization was done according to Adam et al. (1970); Klein and Klein (1970) so as to display the difference between the two venation pattern.

\section{Phytochemical screening}

$30 \mathrm{~g}$ of each leaf sample was extracted by maceration in $400 \mathrm{~mL} 80 \%$ of methanol, shaken and left for $48 \mathrm{~h}$. The mixture was filtered and the residue was remacerated for $24 \mathrm{~h}$ (two more times) in order to obtain adequate quantity of extract. The filtrates were combined and concentrated under reduced pressure at about $40{ }^{\circ} \mathrm{C}$ with the use of a vacuum rotary evaporator (Eyela N-1001). The concentrated extract was used for the phytochemical screening using the standard procedures as described by Sofowora (1993), Trease and Evans (1996), and Harborne (1973).

Determination of tannins. $5 \mathrm{~mL}$ of each sample extract was measured into a test tube and $0.1 \% \mathrm{FeCl}_{3}$ was added and observed for brownish green or a blue black coloration which signifies the presence of tannins.

Determination of terpenoids. $5 \mathrm{~mL}$ of the sample extract was mixed with $2 \mathrm{~mL}$ of $\mathrm{CHCl}_{3}$ in a test tube; $3 \mathrm{~mL}$ of concentrated $\mathrm{H}_{2} \mathrm{SO}_{4}$ was added to the mixture to form a layer. An interface with a reddish brown coloration is formed if terpenoids are present.

Determination of phenolic compounds. $0.5 \mathrm{~g}$ of the extract was dissolved in $5 \mathrm{~mL}$ of distilled water. Few drops of neutral 5\% Ferric chloride solution were added. A dark green color indicated the presence of phenolic compounds.

Determination of saponins. $10 \mathrm{~mL}$ of the extract was mixed with $5 \mathrm{~mL}$ of distilled water in a test tube and shaken vigorously to obtain a stable persistent froth. The frothing is then mixed with 3 drops of olive oil and for the formation of emulsion which indicates the presence of saponins.

\section{Mineral analysis}

Mineral content of the leaf samples was determined according to AOAC (1990) method. $1 \mathrm{~g}$ of pulverized sample was placed in a crucible and ignited in a muffle furnace at $550{ }^{\circ} \mathrm{C}$ for $6 \mathrm{~h}$. The resulting ash was dissolved in $20 \mathrm{~mL}$ of $\mathrm{HNO}_{3}(10 \%)$, heated slowly for about $20 \mathrm{~min}$ and thereafter filtered. Atomic absorption spectrophotometer (Buck Scientific Model 2010) was used to analyze the filtrate for its mineral content; calcium, magnesium, manganese, iron, copper and zinc while flame photometer was used for the determination of $\mathrm{Na}$ and $\mathrm{K}$ in the filtrate. Blank was prepared with $20 \mathrm{~mL}$ of $\mathrm{HNO}_{3}$ (10\%), heated slowly for $20 \mathrm{~min}$ and filtered thereafter. The filtrate obtained from the blank was also analyzed for its mineral contents by using atomic absorption spectrophotometer and flame photometer accordingly. 


\section{Proximate analysis}

The leaves of each plant were analyzed for moisture, protein, fat, ash, fiber, and carbohydrate contents on dry weight basis by the methods of AOAC (2003). Every analysis was carried out in triplicate.

Moisture. Moisture was determined by oven drying method. $1.5 \mathrm{~g}$ of each leaf sample was accurately weighed into a clean and dried crucible $\left(\mathrm{W}_{1}\right)$. The crucible was placed in an oven at $100-105^{\circ} \mathrm{C}$ for $6-12 \mathrm{~h}$ until a constant weight was obtained. Then the crucible was placed in the desiccator for $30 \mathrm{~min}$ to cool. After cooling, it was weighed again $\left(\mathrm{W}_{2}\right)$. The Percentage moisture was calculated using the following equation:

$$
\% \text { moisture }=\frac{\mathrm{W}_{1}-\mathrm{W}_{2} \times 100}{\text { Weight of the sample }}
$$

Where:

sample

$\mathrm{W}_{1}=$ initial weight of crucible + sample

$$
\mathrm{W}_{2}=\text { final weight of crucible }+
$$

However, moisture free samples were used for the remaining analysis.

Ash content. Clean empty crucible was placed in a muffle furnace at $550{ }^{\circ} \mathrm{C}$ for $1 \mathrm{~h}$, cooled in desiccator and then weight of empty crucible was noted $\left(\mathrm{W}_{1}\right) .1 \mathrm{~g}$ of leaf sample was measured into the crucible $\left(\mathrm{W}_{2}\right)$. The sample was incinerated in muffle furnace at $550{ }^{\circ} \mathrm{C}$ for $4 \mathrm{~h}$. The appearances of gray white ash indicated complete oxidation of all organic matter in the sample. The crucible was retrieved from the furnace, allowed to cool in the dessicator and weighed $\left(\mathrm{W}_{3}\right)$. Percentage ash was calculated by following equation:

$$
\text { \% Ash }=\quad \frac{\mathrm{W}_{3}-\mathrm{W}_{1} \times 100}{\text { Weight of sample }}
$$

Where:

$\mathrm{W}_{3}-\mathrm{W}_{1}=$ Difference in Wt. of ash
Protein content. $1 \mathrm{~g}$ of each sample was mixed with $20 \mathrm{~mL}$ of concentrated $\mathrm{H}_{2} \mathrm{SO}_{4}$ in a heating tube. $1 \mathrm{~g}$ of selenium catalyst was added to the tube and mixture heated inside a fume cupboard. The digest was transferred into a $100 \mathrm{~mL}$ volumetric flask and made up with distilled water. $10 \mathrm{~mL}$ portion of the digest was mixed with equal volume of $40 \% \mathrm{NaOH}$ solution and poured into a Kjeldahl distillation apparatus. The mixture was distilled and the distillate collected into $2 \%$ boric acid containing 3 drops of Zuazaga indicator. A total of $50 \mathrm{~mL}$ distillate was collected and titrated as well. The sample was duplicated and the average value taken. The nitrogen content was calculated and multiplied with 6.25 to obtain the crude protein content. Percentage crude protein content of the sample was calculated by using the following equation:

$$
\% \mathrm{~N}=\frac{(\mathrm{s}-\mathrm{b}) \times \mathrm{n} \times 0.014 \times \mathrm{d} \times 100}{\text { Weight of the sample }}
$$

$\%$ Crude protein $=6.25 \times \% \mathrm{~N}$

Where:

$\mathrm{s}=$ sample titration reading

$\mathrm{b}=$ blank titration reading

$\mathrm{N}=$ normality of $\mathrm{HCl}$

$\mathrm{D}=$ dilution of sample after digestion

$\mathrm{v}=$ volume taken for distillation $0.014=$ miliequivalent weight of nitrogen

Correction factor $=6.25$

Crude fat. Approximately $1.5 \mathrm{~g}$ of moisture free sample was placed in fat free thimble and then introduced in the extraction tube. The Soxhlet flask was filled with $300 \mathrm{~mL}$ of petroleum ether and fitted into the apparatus. Heater was turned on and extraction was allowed to run for $6 \mathrm{~h}$. Thereafter, the ether extract was transferred into a clean pre-weighed glass dish and the ether was evaporated on a water bath. The dish was placed in an oven at $105^{\circ} \mathrm{C}$ for $2 \mathrm{~h}$ and cooled in a desiccator.

The percentage crude fat was determined by using the following formula: 
$\%$ Crude Fat $=\underline{\text { Weight of ether extract } \times 100}$

$$
\text { Weight of sample }
$$

Crude fibre. $1.5 \mathrm{~g}$ leaf sample was put into $200 \mathrm{~mL}$ of $1.25 \%$ of $\mathrm{H}_{2} \mathrm{SO}_{4}$ and boiled for $30 \mathrm{~min}$. The solution and content then poured into Buchner funnel equipped with Muslin cloth and secured with elastic band. This was allowed to filter and residue washed with hot water to free it from acid. The residue was then put into $200 \mathrm{~mL}$ boiling $1.25 \% \mathrm{NaOH}$ and boiled for $30 \mathrm{~min}$, then filtered. The residue was washed twice with alcohol and thrice with petroleum ether. The residue obtained was put in a clean dry crucible and dried in the moisture extraction oven to a constant weight. The dried crucible was removed, cooled and weighed. Then difference of weight (i.e. loss on ignition) is recorded as crucible fiber and expressed in percentage of the original weight. Note: A moisture free and ether extracted sample was used for the crude fiber.

$$
\text { Crude fiber }=\frac{\underline{W}_{1}-W_{2}}{\text { Weight of sample }}
$$

Where:

$\mathrm{W}_{1}-\mathrm{W}_{2}=$ difference in weight due to loss on ignition

Carbohydrate. Carbohydrate content was determined by subtracting the sum of percentage moisture, ash, fat, fiber and protein from $100 \%$.

$$
\begin{gathered}
\text { Carbohydrate }=100-(\% \text { Fiber }+ \text { Moisture }+ \\
\% \text { Protein }+\% \text { Fat }+\% \text { Ash })
\end{gathered}
$$

\section{Results and discussion}

The results of the morphological characteristics, phytochemical, mineral and proximate composition of the parent Codieaum variegatum $\mathrm{cv}$. ovalifolium and its bud sport (mutant) are presented in Tables 1, 2, 3, and 4, respectively.
The vegetative growth characters considered in this study included various parts of a typical leaf namely the leaf length and breadth, apex, venation pattern, petiole length, pulvini and inter-pulvinus coloration. The two pulvini i.e top and bottom are usually whitish while the interpulvinus is pigmented (purple at maturity). The leaf blade (lamina) length and breadth are inferior to those of the mutant. This implies that the mutant is vegetatively more vigorous than the parent plant. This ascertion is obvious from the main length and the breadth of the leaves which are almost twice that of the parent (200\%). The apex of the leaf is obtuse in the parent but acute in the mutant. There are three colors on the adaxial surface (upper) of the parent. These are green, purple and yellow colors. However it is entirely green in the mutant while at maturity both leaves show purple colorations in their abaxial (lower) surfaces. The mutant has deeper coloration of purple than the parent. The shape of the leaf is oval or elliptical in the parent and the surface of the plant is concave unlike that of the mutant which is flat and the general shape is ovate. The mutant is better on rooting ability and in the number of days to rooting, branching and total volume (vigor). Venation pattern is clearly different in the parent compared to the mutant leaves. The mutant has reticulate pinnate venation while the parent has reticulate convergent venation (Figure 1). The number of major veinlets (2) is very low in the parent leaves and very high in the mutant leaves (20-30). The life span of the leaves is also very different; the parent leaves survive 6-12 months with an average of 9 months while the mutant range from 8-20 months with an average of 15 months. As seen in Figure 1, the petiole is very superior and demarcated into top and bottom pulvini and a pigmented inter pulvinus giving the petiole shape in the mutant something like the 'taking drum' in Nigeria while in the parent leaf petiole, the shape is like a mini club-like structure. 
Table 1. Comparative leaf morphometry (morphological measurement) of plants of the parent $c v$. ovalifolium and the mutant (bud-sport)

\begin{tabular}{|c|c|c|}
\hline Characters & Parent ovalifolium & Mutant \\
\hline \multicolumn{3}{|l|}{ Leaf-blade (lamina) } \\
\hline \multicolumn{3}{|l|}{ - Length: } \\
\hline mean $\ddot{x}$ & 11.3 & 25.2 \\
\hline range & $9.1-18.5$ & $15-32$ \\
\hline \multicolumn{3}{|l|}{ - Breadth: cm } \\
\hline mean $\ddot{x}$ & 6.5 & 13.1 \\
\hline range & $5.1-10.2$ & $9.2-14.0$ \\
\hline - Apex & Obtuse & Acute \\
\hline - Dominant colours & Mix green, purple yellow & $\begin{array}{l}\text { Green adaxial purple or maroon } \\
\text { abaxial }\end{array}$ \\
\hline - Surface & Glabrous & Glabrous \\
\hline - Shape & Oval/elliptical & Ovate \\
\hline \multicolumn{3}{|l|}{ - Days to rooting } \\
\hline mean $\ddot{x}$ & 55 & 35 \\
\hline range & $45-60$ & $24-40$ \\
\hline \multicolumn{3}{|l|}{ - Venation pattern: } \\
\hline Reticulate pinnate (r) & & $\mathrm{R}$ \\
\hline Reticulate convergent (c) & $\mathrm{C}$ & \\
\hline No. major veinlets & 2 & $20-30$ \\
\hline \multicolumn{3}{|c|}{ - Duration of leaf (life-span) } \\
\hline mean & 9.0 months & 15.0 months \\
\hline (months) range & $6-12$ & $8-20$ \\
\hline \multicolumn{3}{|l|}{ Petiole } \\
\hline \multicolumn{3}{|l|}{ • Length: } \\
\hline mean $\mathrm{cm}$ & 2.0 & 2.7 \\
\hline range $\mathrm{cm}$ & $0.5 \mathrm{~cm}-2.4$ & $1.5-3.4$ \\
\hline Thickness (breath) & $0.2-0.4$ & $0.5-0.7$ \\
\hline \multicolumn{3}{|l|}{ Pulvinus length $(\mathrm{cm})$} \\
\hline upper- mean $\mathrm{cm}$ & 0.5 & 0.9 \\
\hline - range & $0.1-0.8$ & $0.5-1.1$ \\
\hline lower- mean cm & 0.2 & 0.16 \\
\hline - range & $0.04-0.3$ & $0.5-1.9$ \\
\hline colour(s) (a) petiole & White & White \\
\hline (b) interpulvinus & Purple & Purple \\
\hline upper- mean $(\mathrm{cm})$ & 0.3 & 1.1 \\
\hline - range $(\mathrm{cm})$ & $0.2-0.4$ & $1.0-1.2$ \\
\hline Petiole shape & Club-like & Talking drum Nigerian \\
\hline \multicolumn{3}{|l|}{ Number of leaves/flush } \\
\hline mean & 11.0 & 24 \\
\hline Range & $9-10$ & $15-28$ \\
\hline
\end{tabular}

Finally, leaves are produced in flushing i.e. a cycle of leaves that increases the ability to shade or capture sunlight for photosynthesis. The range is about 9-10 leaves per flush with an average of 11 leaves per flush in the parent plant while a range of 15-28 leaves were found per flush with an average of 24 in the mutant. So far, there is no leaf morphometric report on the garden croton mutant in the literature search on this subject.

The results of the phytochemical screening of the parent plant (ovalifolium) and its mutant as presented in Table 2 showed the presence of phenolic compounds, saponins, terpenoids in both 
parent leaf and the mutant while flavonoids were absent in both. Cardiac glycosides and tannins were highly present in the parent plant but slightly present in the mutant. Terpenoids are aromatic compounds that have important pharmaceutical properties in cancer treatment, male and female contraceptives and a number of plant growth regulators are derived from terpenoids biosynthesis (Caroline et al., 2008). Cardiac glycosides are involved in the treatment of heart failure and certain irregular heartbeats. Pure cardiac glycosides administered as injection or tablets inhibits active transport of $\mathrm{K}$ and $\mathrm{Na}$ through membranes thereby strengthening heart muscles and the power of systolic concentration against congestive heart failure (Clifford and Gessener, 1973). Saponins protect against hyperchlolesterolemia. It has antibiotic properties (Amin et al., 2013). Tannins are used in wine production especially red wine. Tannins add both bitterness and astringency and also serve as deterrents and antifungal agents (Caroline et al., 2008). Phenolic compounds serve a variety of functions in plants, from poisons to antibacterial compounds to plant pigments and scents (Caroline et al., 2008). This observation is comparable to that of Ogunwenmo et al. (2007). However it is necessary to note that a generalization may not be possible with respect to medicinal value.
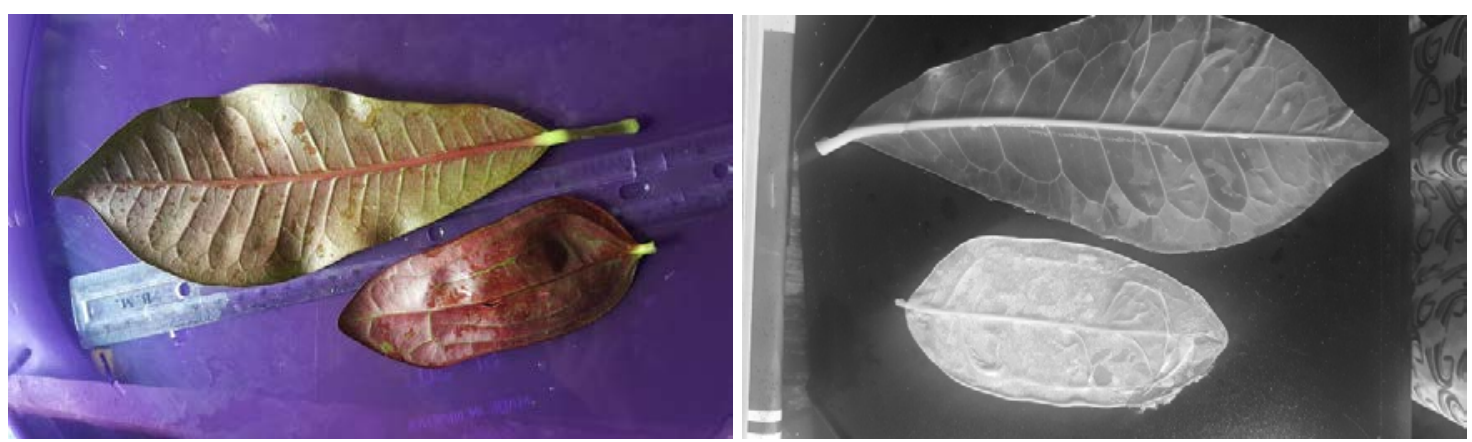

Figure 1. Different venation patterns: contrast in the mutant (top) and the parent plant; ovalifolium (bottom). Both patterns are reticulate type of venation.

Table 2. Phytochemical screening of Codiaeum variegatum (ovalifolium) and its mutant.

\begin{tabular}{|l|c|c|c|}
\hline S/N & Phytochemical & Ovalifolium & Mutant \\
\hline 1 & Terpenoids & ++ & ++ \\
\hline 2 & Cardiac Glycosides & ++ & - \\
\hline 3 & Flavonoids & - & + \\
\hline 4 & Tannins & ++ & ++ \\
\hline 5 & Phenolic compound & ++ & ++ \\
\hline 6 & Saponin & ++ \\
\hline
\end{tabular}

Table 3 shows the results of the mineral contents of ovalifolium and its mutant. The minerals determined in this study were calcium, magnesium, potassium, iron, copper, zinc and sodium which were found at varied concentrations in the parent plant and its mutant. Of all the minerals assayed for in both the parent and mutant, Calcium was found occurring at the highest concentration while copper occurred at the least concentration. The trend of occurrence of the metals for both parent and mutant 
was; $\mathrm{Ca}>\mathrm{K}>\mathrm{Mg}>\mathrm{Na}>\mathrm{P}>\mathrm{Fe}>\mathrm{Zn}>$ $\mathrm{Cu}$. The parent plant showed higher concentration of Calcium, Magnesium, Potassium, Iron, Copper, and Zinc than the mutant while copper was found to be absent in the parent. Sodium was however higher in the mutant than in the parent plant.
Sodium is not a regularly element or micro element. The exact role of sodium in the nutrition of plant is still been explored. Micro nutrients function in plant mainly as co-factor non protein helper in an enzymatic reaction.

Table 3. Mineral content of Codiaeum variegutum (ovalifolium) and its mutant.

\begin{tabular}{|l|c|c|c|c|c|c|c|c|c|}
\hline S/N & Cultivar & Ca (\%) & Mg (\%) & $\mathbf{K}(\%)$ & Na (\%) & P (\%) & Fe (\%) & Cu (\%) & $\mathbf{Z n ~ ( \% ) ~}$ \\
\hline 1 & Ovalifolium & $2.56 \pm 0.03$ & $0.51 \pm 0.01$ & $1.98 \pm 0.01$ & $0.36 \pm 0.01$ & $0.20 \pm 0.01$ & $0.03 \pm 0.001$ & $0.00 \pm 0.00$ & $0.01 \pm 0.00$ \\
\hline 2 & Mutant & $2.14 \pm 0.02$ & $0.44 \pm 0.01$ & $1.74 \pm 0.02$ & $0.39 \pm 0.01$ & $0.12 \pm 0.01$ & $0.02 \pm 0.01$ & $0.001 \pm 0.00$ & $0.006 \pm 0.00$ \\
\hline
\end{tabular}

Data are expressed as mean \pm standard error of three replicates.

Generally, both plants, especially the parent are rich in calcium, magnesium, phosphorus, and potassium. These minerals are essential for plant survival .Calcium is important for stability of cells walls and in maintenance of membrane structure and permeability. It also helps to regulate many responses of cell to stimuli in plant (Campbell et al., 2008). Calcium also plays an important role in building and maintaining strong bones and teeth. It is also necessary for normal functioning of cardiac muscles, blood coagulation, milk clotting and regulation of cell permeability (Heaney, 1994). Magnesium is part of the component of chlorophyll and some enzymes in the plant (Dutta, 2004; Campbell et al., 2008) and also plays important roles in formation and function of bones, muscles. It prevents high blood pressure and depression in humans (Smith and Hammarsten, 1958). Potassium is a cofactor that functions in protein synthesis, major solute functioning in water balances, operation of stomata in the plant and helps in release of chemicals which act as nerve impulses, regulates heart rhythms. Its deficiency causes nervous irritability, mental disorientation, low blood sugar, insomnia and coma in human (Underwood and Suttle, 1999).

The results of the proximate composition of ovalifolium leaves and its mutant are shown in Table 4. These results showed that the parent plant contained ash (12.58\%), crude protein (3.12\%), crude fat (6.52\%), crude fiber (19.52\%), carbohydrate $(57.77 \%)$ moisture $(0.4932 \%)$ and the mutant contained ash (10.96\%), crude protein (10.25\%), crude fat (9.735\%), crude fiber (33.78\%), carbohydrate (35.21\%) and moisture $(0.0615 \%)$ on dry weight basis. These results showed that the plants contained considerably high amount of ash, protein, fat, fiber and carbohydrate. The parent plant however contained more moisture, ash and carbohydrate while the mutant contained more fat, fiber and protein. These results showed that these plants possess considerably good food value.

Table 4. Proximate analysis result of the Codiaeum variegatumand its mutant (on dry weight basis)

\begin{tabular}{|l|l|l|l|}
\hline S/N & Proximate parameter & Ovalifolium & Mutant \\
\hline 1 & Moisture content (\%) & $0.4932 \pm 0.02$ & $0.0615 \pm 0.01$ \\
\hline 2 & Ash content (\%) & $12.575 \pm 0.21$ & $10.96 \pm 0.12$ \\
\hline 3 & Crude protein (\%) & $3.12 \pm 0.03$ & $10.25 \pm 0.10$ \\
\hline 4 & Crude fiber (\%) & $19.52 \pm 0.05$ & $33.78 \pm 0.23$ \\
\hline 5 & Crude fat (\%) & $6.52 \pm 0.11$ & $9.735 \pm 0.11$ \\
\hline 6 & Carbohydrate (\%) & $57.77 \pm 1.00$ & $35.21 \pm 1.20$ \\
\hline
\end{tabular}

Data are expressed as mean \pm standard error of three replicates. 


\section{Conclusion}

This study showed the presence of important phytochemicals, minerals and proximate parameters in ovalifolium and its mutant. This implies that these plants may possess good potentials for food and medicine. However further investigations should be carried out to comparatively quantify the phytochemicals present in these plants. This would help to determine relatively the medicinal or pharmaceutical usability of these plants against specific diseases.

\section{References}

Amin, M. M.; Sawhey, S. S.; Jassal, M. M. S. Qualitative and quantitative of phytochemicals of Taraxacum officinale. Journal of pharmacy and pharmacology, v. 2, No. 1, p. 1- 5, 2013.

AOAC - Association of Official Analytical Chemists. Official Method of Analysis. 15. ed. Washington, DC: AOAC, 1990.

AOAC - Association of Official Analytical Chemists. Official Method of Analysis. 17. ed. Arlington, Virginia: AOAC, 2003.

Balch, P. A.; Balch, J. F. Prescription for nutritional healing. 3. ed. Avery Penguin JK Putnam, 2000. p. 117-206.

Campbell, N. A.; Reece, J. B.; Urry, L. A.; Cain, M. L.; Wasserman, S. A.; Winickoff, B.; Jackson, R. B. Biology. 8. ed. Pearson Publisher, 2008. p. 101.

Caroline, B.; Martin, S.; Alyson, T. Plant biochemitry. New York: Garland Science Group, 2008.

Clifford, A. H.; Gessener, G. H. The encyclopedia of Chemistry. 3. ed. New York: Van Nostrand Reinhold Company, 1973.

Dutta, A. C. Botany for degree student. 6. ed. London, UK: Oxford University Press, 2004.

Esan, E. B.; Denton, O. A.; Ayodele, A. E.; Ogunwenmo, K. O.; Fapohunda, S. O. The establishment of the Babcock University Garden Croton Germplasm Repository.
Babcock University Academic Congregation Colloquium Series. v. 2, p. 29-36, 2005.

Fapohunda, S. O.; Esan, E. B.; Ogunwenmo, K. O.; Adedayo, A. Report of Fusarium Oxysporum on Codiaeum variegatum (L.) Blume (Euphorbiaceae) cultivars in Nigeria. Journal of life and Physical Science, v. 2, No. 1, p. 40-41, 2005.

Harborne, J. Phytochemical methods. London: Chapman and Hall, 1973.

Heaney, R. D. Thinking straight about calcium. The New England Journal of Medicine, v. 328, No. 7, p. 503-505, 1994.

Klein, R. M.; Klein, D. T. Research Methods in Plant Science. The National History press, Garden city, New York, p. 93, 1970.

Mwine, J. T.; Damme, P. V. Why do Euphorbiaceae tick as medicinal plants? a review of Euphorbiaceae Family and its medicinal features. Journal of Medicinal Plants Research, v. 5, p. 652-662, 2011.

Ogunwenmo, K. O.; Idowu, O. A.; Innocent, C.; Esan, E. B.; Oyelana, O. A. Cultivars of Codiaeum variegatum (L) Blume (Euphorbiaaceae) show variability in phytochemical and cytological characteristics. African Journal of Biotechnology, v. 6, p. 2400-2405, 2007.

Ronald, J. K.; Seymour, B. Plant science. Ronald Journal Konopka, v. 68, No. 9, p. 2112-2116, 1971.

Smith, W. D.; Hammersten, J. F. Serum Mg in clinical disorder. South Molecular Journal, v. 51, p. 1116-1117, 1958.

Sofowora, A. Medicinal plants and traditional medicine in Africa. New York: Cheschester John Wiley and sons, 1993.

Taylor, N. The garden dictionary and the practical encyclopedia of garden horticultures and landscapes design. Garden city NY USA: Garden E. B. City Pub. Comp., 1938.

Taylor, D. J.; Green, N. P. O.; Stout, G. W.; Soper, R. Biological science. 3. ed. Cambridge: University Of Cambridge, 2002.

Trease, G. E.; Evans, W. C. A textbook of pharmacognosy. 14 . ed. London: Bailliere Tindall, 1996. 
Underwood, E. J.; Suttle, N. F. The mineral nutrition of Livestock, CABI publishing, New York, 51-101, 1999.

Xue, X.; Lili, Z.; Binmei, L.; Yafeng, Y.; Yuejin, W. Characterization and mapping of a spotted leaf mutant in rice (Oryza sativa).

Genetics and Molecular Biology, v. 37, No. 2, p. 406-413, 2014.

License information: This is an open-access article distributed under the terms of the Creative Commons Attribution License, which permits unrestricted use, distribution, and reproduction in any medium, provided the original work is properly cited.

Braz. J. Biol. Sci., 2017, v. 4, No. 7, p. 25-34. 